\title{
DEVELOPMENT OF PLANT LEAF AREA MEASUREMENT APPARATUS
}

\author{
OBAIA, A. R ${ }^{1}$. and A. M. DREES ${ }^{2}$
}

1. Agric. Eng. Res. Institute, ARC, Dokki, Giza, Egypt.

2. Agric. Eng. Dept., Fac. of Agric., Al-Azhar Univ. Assuit.

(Manuscript received 20 December 2016 )

\begin{abstract}
$\mathrm{E}$ xperimental study was carried out at the Agricultural Engineering Department, Faculty of Agriculture, Omar ElMokhtar University, Al-Beida, Libya. The objective of this study to develop apparatus for measuring plant leaf area based on the changes on resistance of air pressure as related to surface area of plant leaf.The results showed that, for predicting the change of leaf area at different air pressure, a series of simple regression analysis was employed. The analysis related the change in leaf area with air pressure. The regression analysis could relate the change in leaf area strongly with the air pressure as indicated by the high regression coefficients of the obtained equations. On the other hand, it can be seen power relationship between the leaf area $(\mathrm{Y})\left(\mathrm{cm}^{2}\right)$ and air pressure $(\mathrm{X})(\mathrm{m} . \mathrm{bar})$, and this relationship submitted to the following equation:

$$
Y=9.8624 X^{0.6945} \quad\left(R^{2}=0.9564\right)
$$

The accounting data of leave areas using the apparatus and a standardplanimeterwere recorded to obtain correction factor. The correction factor was $0.84,0.85,0.86,0.87,0.90,0.92,1.02,1.05$, 1.08 and 1.09 for leaves area; Olive, Lemon adalia, Marble, Bots, Almond, Garonaa, Grape, Roses, Peach and Plum, respectively. The average value of correction factor was found to be 0.96 of plant leaf area.

Keywords: plant leaf area; planimeter; developed apparatus ; prediction equation.
\end{abstract}

\section{INTRODUCTION}

Reviews of leaf area determination techniques indicated that, leaf area meter is the usual method, although planimeters, photogravimetric methods and arealength regression equations are also used. Direct leaf area measurement methods are generally simple and reliable but are usually tedious. The planimeter is a simple instrument traditionally used to measure area of maps and closed boundaries, and is also used for leaf area measurement.

Knowledge of leaf area is an important parameter in understanding photosynthesis, light interception, water and nutrient use, crop growth, and yield potential (Williams, 1987). Measurement of leaf area is of value instudies of plant nutrition, plant competition, plant soil-water relations, plant protection measures, crop 
ecosystems, respiration rate, light reflectance, and heat transfer in heating and cooling processes. The importance of leaf area determination in plant sciences has stimulated the use of a great variety of methods for leaf area measurement. Some of the basic methods are graphical method, length and width correlation, leaf specific weight correlation, and usage of electronic devices (Mohsenin, 1986). The leaf area (LA) of a specified plant species indicates the performance of mechanisms such as radiation interception, water and energy exchange, crop growth and bio-productivity. LA has been proven to be of great significance in plant growth studies and has helped with the understanding of plant-environment interactions (De Jesus et al., 2001; Gyves et al., 2008).Precise determination of LA is necessary because LA is a fundamental component of crop growth models(Lizaso etal., 2003; Bonser and Aarssen, 2009). To evaluate continuous changes in LA and the subsequent growth, a modeling approach is essential (Bonser and Aarssen, 2009). Moreover, accurate estimation of LA is thus crucial to understanding and modeling ecosystem function (Antunes etal., 2002).Blanco and Folegatti (2003) indicates that one of the most frequently used non-destructive methods is LA estimation from mathematical equations involving linear measurement; such as leaf length, or leaf width, or some combination of these variables, this is generally preferable because of their simplicity and accuracy.However, models developed by this method are suitable only for a specific plant. A portable scanning planimeter is only suitable for small plants with few leaves and not feasible for large leaves (Nyakwende et al., 1997; Rouphael et al., 2010). Therefore, models for non-destructive prediction of the leaf area, i.e. algometry, are useful tools for researchers in horticultural experiments. For example, such models enable researchers to measure leaf area on the same plants during the plant growth period and that may reduce variability in the experiments (Tsialtas and Maslaris, 2005). The use of simple linear measurement for predicting the LA of horticultural plants eliminates the need for costly leaf area meters(Antunes etal., 2002; Kumar, 2009 and Peksen, 2007). Somehow, the development of statistical regression models from linear leaf measurements to predicting total or individual leaf area has been shown to be very applicable(Achten etal., 2010; Demirsoy etal., 2005; Tsialtas and Maslaris, 2005 and Serdar and Demirsoy, 2006). So, the present study aims to develop apparatusfor measuring plant leaf area based on the changes on resistance of air pressureas related to surface area of plant leaf. 


\section{MATERIALS AND METHODS}

\section{Materials}

This study was conducted in theDepartment of Agricultural Engineering, Faculty of Agriculture, Omar El-Mokhtar University, Libya,to developapparatusfor measuring plant leafarea.Thedeveloped apparatus based on determining the resistance changes of air pressureas related to surface area of plant leaves.The used plants for the experimental work includedOlive; Lemon adalia; Marble; Bots; Almond; Garonaa; Grape; Roses; Peach andPlum.

\section{Description of the developed apparatus}

It consists of anelectrical motor and air blower with a fan of $18 \mathrm{~cm}$ internal diameter and $25 \mathrm{~cm}$ external diameterand specifications of (Type: DF-3, Vol.: 504 $\mathrm{m}^{3} / \mathrm{h}$, Power $0.25 \mathrm{~kW}$, Speed: 2800 r.p.m, Pressure: $880 \mathrm{~Pa}$ ) as shown in Figs. (1a and b). An air flow line consists of a horizontal pipe $(5 \mathrm{~cm}$ diameter and $40 \mathrm{~cm}$ length); and a valve for controlling air discharge was used. The horizontal pipe connected with another vertical pipe (5 cm diameter and $50 \mathrm{~cm}$ length). A cap pipe with $10 \mathrm{~cm}$ diameter and $20 \mathrm{~cm}$ length was assembled at the upper end of the vertical pipe and covered with a circular screen $12 \mathrm{~cm}$ diameter. The screen was used for leaves accommodation during the experimental tests.

Pressure gauge with indicator from 0 to $100 \mathrm{~m}$.bar was assembled on the cap pipe as for measuring air pressure directly beneath the tested plant leaves. An electric switch was used for blower turning on/off and another velocity control switch for changing the r.p.m of the blower shaft. The changed speed of the blower results on different pressure over the measured surfaces of the tested leaves. The whole developed apparatus was loaded on wooden table $(0.4 \times 0.4 \mathrm{~m})$ with steel leg and frame (0.8 $\mathrm{m}$ high). 


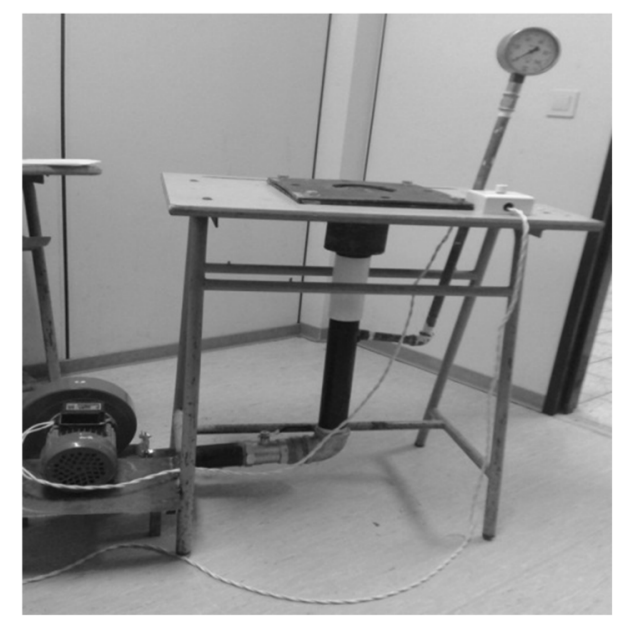

a

1-Electric motor. 2-Air blower. 3-Wooden table. 4-Air valve.

5- circular screen. 6- Pressure

gauge.

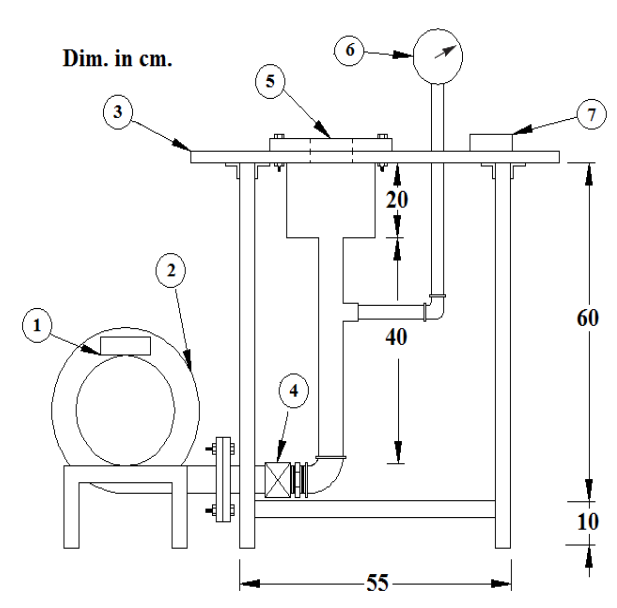

b switch.

Figs. ( $1 \mathrm{a}$ and $\mathrm{b}$ ). The developed apparatus used for measuring plant leaf area.

\section{Methods:}

\section{Calibration of developed apparatus:}

Some pieces of artificial paper with known areas from 15 to $100 \mathrm{~cm}^{2}$ were used for calibrate the developed apparatus. The air pressurewas measured before and after putting the known sample over the surface of the testing screen. The recorded data were assigned for examining the validity of the pressure change system for area measurement and also getting a relationship model relating the leaf surface area with the applied pressure.A laboratory testswere also made with actual samples of plant leaves to compare the measurements of leaves area using the developed apparatus and by the planimeter as standard measuring method for leaf area.The accuracy of measurement of the developedapparatuswhich depends on the magnitude of the pressure change per unit area was compared with the measurements of the planimeter. The planimeter with specifications: AM 200- Model No.: SE213C- FCC ID: EMJSE203C- Made in Tiwan R.O.C shown in Fig. (2) was used to measure the standard leaf area.

\section{Operating steps:}

After turning the fan motor, samples of different studied plants were accommodated over the surface of the apparatus screen and air flow from the fan was gradually increased through the control valve till the tested leave starts to float 
over the screen surface. At this point the air pressure also measured and recorded. The recorded data were used to perform a calibration curve relating the recorded air pressure with the leaf area. The measured areas using the developed apparatus and the planimeter was related and a correction factor was defined for each type of studied leaves.

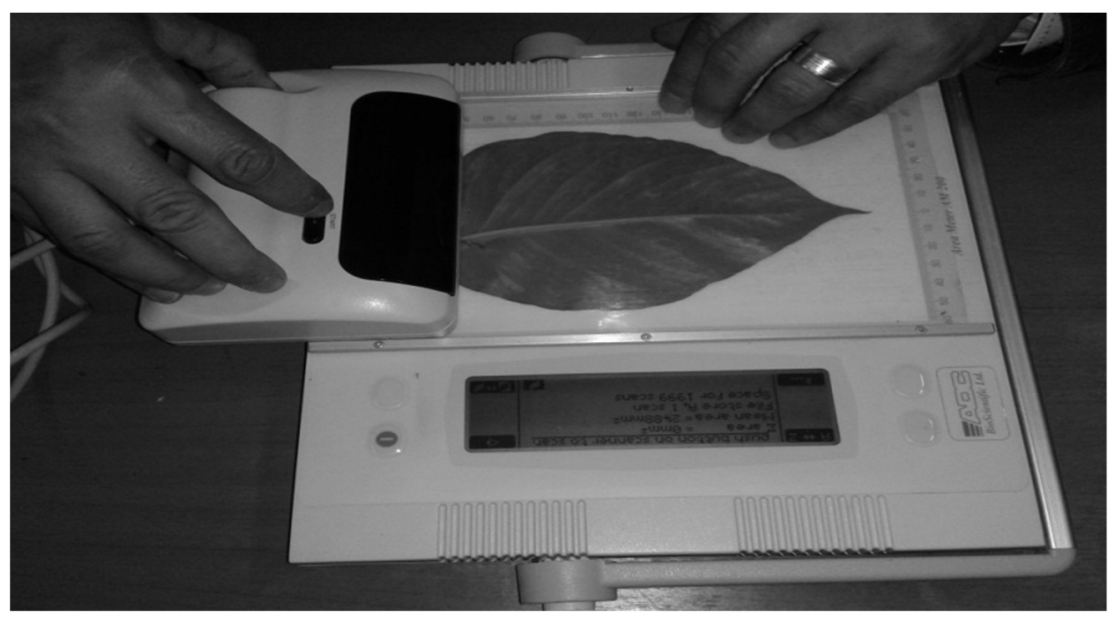

Fig. (2). Method of plant leaf measuring by planimeter.

\section{RESULTS AND DISCUSSION}

The developed apparatus used to measure leaf area by installingartificial paper samples with known areas from 15 to $100 \mathrm{~cm}^{2}$ on the screen of developed apparatus and recording the measure data before and after installing the artificial paper over the screen. After measurements, the actual pressure over the paper surface was calculated as illustrate in Table (1).For relating the change of leaves areawith different applied air pressures, a series of simple regression analysis was employed. The analysis related the change in leaf area with the applied air pressure.The obtain regression equations are presented in Fig. (3). As shown in the figure (4) the regression analysis could relate the change in leaves area strongly with the applied air pressure as indicated by high regression coefficients of the equations. On the other hand, apowerrelationship was found between leaf area $(Y)\left(\mathrm{cm}^{2}\right)$ and air pressure $(X)$ (m.bar). This relationship was formed the following equation (1):

$$
Y=9.8624 X^{0.6945} \quad\left(R^{2}=0.9564\right)
$$


This means that, there is a relationship between the leaves area and the applied air pressure. A similar tests were conducted for actual plant leaves (Olive,Lemon adalia; Marble; Bots; Almond; Garonaa; Grape; Roses; Peach andPlum). The measured data using the developed apparatus and the planimeter were also compared and a relationship between the measured data using both apparatus was developed.

Table 1. Calibration of the developed apparatus by known leave areas.

\begin{tabular}{|c|c|c|c|}
\hline \multirow{2}{*}{ leaf area, $\mathrm{cm}^{2}$} & \multicolumn{2}{|c|}{ air pressure through the screen, m.bar } & \multirow{2}{*}{ Different of the air pressure, m.bar } \\
\hline & without sample & $\begin{array}{c}\text { with } \\
\text { sample }\end{array}$ & \\
\hline 15 & 3 & 5.0 & 2.0 \\
\hline 20 & 3 & 6.6 & 3.3 \\
\hline 25 & 3 & 6.0 & 3.0 \\
\hline 30 & 3 & 10.3 & 6.1 \\
\hline 35 & 3 & 8.0 & 5.0 \\
\hline 40 & 3 & 12.1 & 9.1 \\
\hline 45 & 3 & 10.0 & 7.0 \\
\hline 50 & 3 & 15.8 & 12.8 \\
\hline 55 & 3 & 16.8 & 13.8 \\
\hline 60 & 3 & 14.0 & 11.0 \\
\hline 65 & 3 & 19.6 & 16.6 \\
\hline 70 & 3 & 23.0 & 20.0 \\
\hline 75 & 3 & 21.0 & 18.0 \\
\hline 80 & 3 & 24.0 & 21.0 \\
\hline 85 & 3 & 23.0 & 20.0 \\
\hline 90 & 3 & 27.0 & 24.0 \\
\hline 95 & 3 & 25.0 & 22.0 \\
\hline 100 & 3 & 28.0 & 25.0 \\
\hline
\end{tabular}




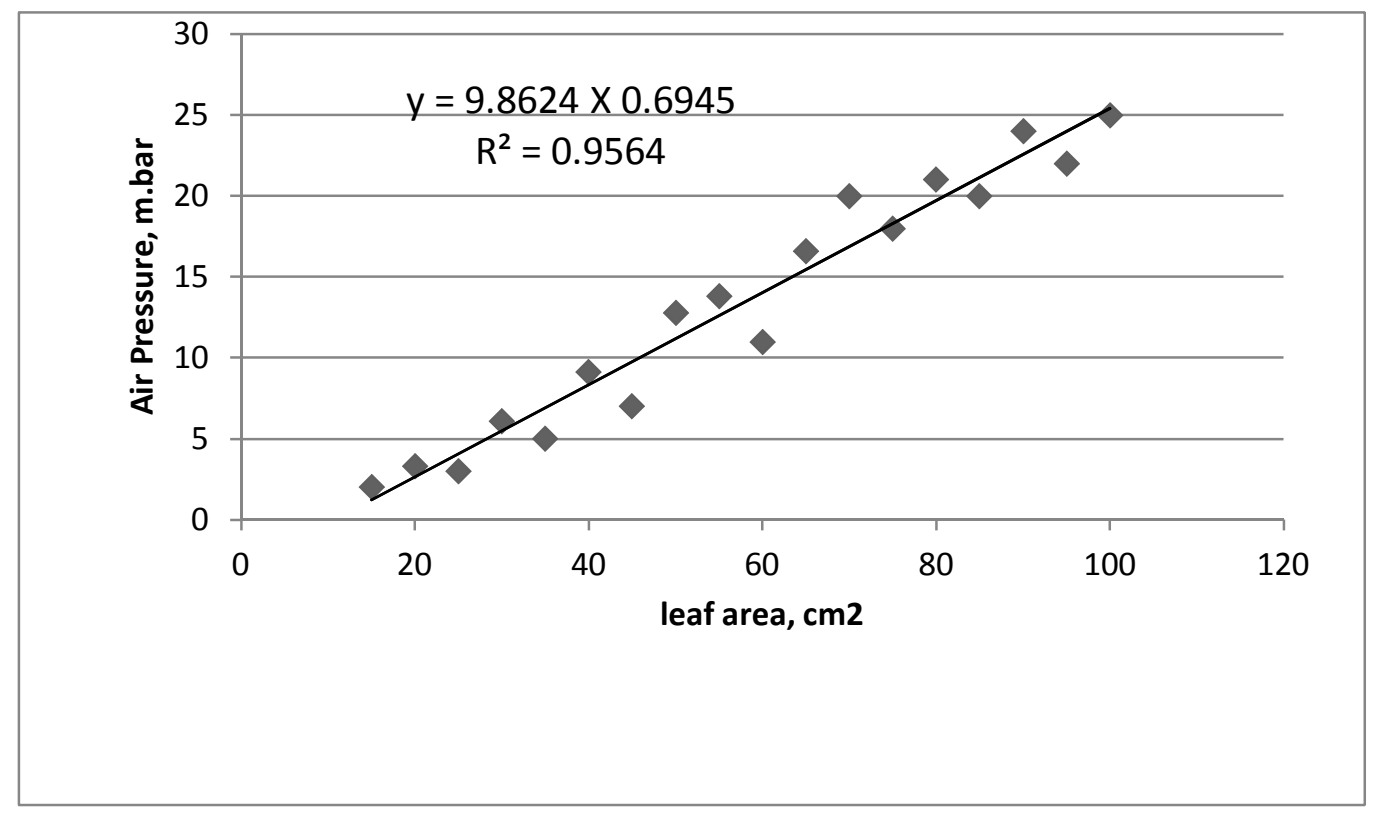

Fig. (3). The relationship between leaf area, $\mathrm{cm}^{2}$ and air pressure, m.bar.

The recording data of leaves area using the developed apparatus with the measure area using the planimeterwere recorded for obtain correction factor and summarized in Table (2). As shown in Table (2) the correction factoras0.84, 0.85, $0.86,0.87,0.90,0.92,1.02,1.05,1.08$ and 1.09 for plant leaf area, Olive; Lemon adalia; Marble; Bots; Almond; Garonaa; Grape; Roses; Peach andPlum, respectively. The average value of correction factor was found to be 0.96 of plant leaf area.

Table 2. Correction factor of plant leaves area with planimeter and the developed apparatus.

\begin{tabular}{|c|c|c|c|}
\hline Plant type & $\begin{array}{l}\text { Area fromPlanimeter } \\
\qquad\left(\mathrm{cm}^{2}\right)\end{array}$ & $\begin{array}{c}\text { Area from the developed } \\
\text { apparatus } \\
\left(\mathrm{cm}^{2}\right)\end{array}$ & $\begin{array}{l}\text { Correction } \\
\text { factor* }\end{array}$ \\
\hline Olive & $\Lambda, r_{0}$ & $9, \vee \uparrow$ & $\cdot, 10$ \\
\hline Lemon adalia & $r_{\bullet}, \varepsilon \wedge$ & $r r, 9 \Lambda$ & $\cdot, 10$ \\
\hline Marble & $r \leqslant, 7$. & $r A, r \varepsilon$ & $\cdot, A \vee$ \\
\hline Bots & $\because, \wedge$. & $v \cdot, \wedge \wedge$ & $\cdot, A V$ \\
\hline Almond & ro,or & $r \Lambda, Y \leqslant$ & $\cdot, 9$. \\
\hline Garonaa & $V 1,7 v$ & $V \wedge, T V$ & $\cdot, 94$ \\
\hline Grape & $r 9, .0$ & $r \Lambda, 19$ & $1, \cdot r$ \\
\hline Roses & 01,17 & $\{\Lambda, V)$ & $1, .0$ \\
\hline Peach & $\varepsilon 0, \wedge \varepsilon$ & $\leq r, \leq 7$ & $1, \cdot 1$ \\
\hline Plum & $r 1,01$ & $19, v 1$ & $1, .9$ \\
\hline
\end{tabular}

* Correction factor $=$ area from planimeter/area from developed apparatus 


\section{CONCLUSION}

It can be concluded that, the developed apparatus can be used for measuring leaves areaon the basis of change inair pressure.The values of the correction factor for the plant leaves area could be used for Eq. (1) to get a very close values of the measured surface area for different studied plants.

\section{REFERENCES}

1. Achten WMJ; WH. Maes; B. Reubens; E. Mathijs; VP Singh and L. Verchot. 2010. Biomass production and allocation in Jatropha curcas L. seedlings under different levels of drought stress. Biomass Bioenerg; 34(5):667-676.

2. Antunes WC; MF Pompelli; DM Carretero and FM DaMatta. 2008. Algometric models for non-destructive leaf area estimation in coffee (Coffeaarabica and Coffeacanephora). Ann Appl Biol.; 153(1):33-40.

3. Blanco F.F. andM.V. Folegatti. 2003. A new method for estimating the leaf area indexof cucumber and tomato plants. Hortic. Bras. 21 (4), 666-669.

4. Bonser SP. And LW. Aarssen. 2009. Interpreting reproductive allometry: individual strategies of allocation explain size-dependent reproduction in plant populations. Perspect Plant Ecol.; 11(1):31-40.

5. Coombs J.; D.O. Hall; S.P. Long and J.M.O. Scurlock. 1985. Techniquesin Bioproductivity and Photosynthesis, seconded. Pergamon Press, Oxford, pp.45-46.

6. De Jesus W.C.J.; F.X.R. Do Vale; R.R. Coelho and L.C. Costa. 2001. Comparison oftwo methods for estimating leaf area index on common bean. Agron. J. 93,989-991.

7. Demirsoy H; L. Demirsoy andA.O" ztu" rk. 2005. Improved model for the nondestructive estimation of strawberry leaf area. Fruits; 60 (1):69-73.

8. Gyves, E.M.; V. Cristofori; C. Fallovo; Y. Rouphael and C. Bignami. 2008. Accurate andrapid technique for leaf area measurement in medlar (Mespilusgermanica L.).Adv. Hortic. Sci. 22 (3), 223-226.

9. Kumar R. 2009. Calibration and validation of regression model for non-destructive leaf area estimation of saffron (Crocus sativus L.). Sci Hortic-Amsterdam; 122(1): 142-145.

10. Kvet J.and J.K. Marshall. 1971. Assessment of leaf area and other assimilating plant surfaces. In: Sesta'k, Z., Catsky', J., Jarvis, P.G. (Eds.), Plant Photosynthetic Production. Manual of Methods. The Hague, Dr W. Junk. 1971, pp. 517-555.

11. Lizaso JI; WD. Batchelor and ME. Westgate. 2003. A leaf area model to simulate cultivar-specific expansion and senescence of maize leaves. Field Crop Res.; 80(1):1-17. 
12. Mohsenin N. N. 1986. Physical Properties of Plant and Animal Materials. Gordon and Breach Science Publishers, New York, pp. 107-110.

13. Nyakwende E.; C.J. Paulland J.G. Atherton. 1997. Non-destructive determination ofleaf area in tomato plants using image processing. J. Hortic. Sci. Biotechnol. $72,225-262$.

14. Peksen E. 2007. Non-destructive leaf area estimation model for faba bean (Viciafaba L.). Sci. Hortic-Amsterdam; 113(4):322-328.

15. Rouphael Y.; A.H. Mouneimne; A. Ismail; E.M. Gyves; C.M. Rivera and G. Colla. 2010. Modeling individual leaf area of rose (Rosa hybrid L.) based on leaf length andwidth measurement. Photosynthetica 48, 9-15.

16. Serdar U.and H. Demirsoy. 2006. Non-destructive leaf area estimation in chestnut. Sci. Hortic-Amsterdam; 108(2):227-230.

17. Suggs C.W.; J.F. Beeman and W. E. Splinter. 1960. Physical properties of green Virginia-type tobacco leaves. Part III. Relation of leaf length and width to leaf area. Tobacco Sci. 4, 194-197.

18. Tsialtas JT. and N. Maslaris. 2005. Leaf area estimation in a sugar beet cultivar by linear models. Photosynthetica; 43(3):477-479.

19. Williams L. E. 1987. Growth of 'Thompson Seedless' grapevines. I. Leaf area development and dry weight distribution. J. Am. Soc. Hort. Sci. 112, 325-330. 


\section{تطوير جهاز لقياس مساحة أوراق النبات}

$$
\begin{aligned}
& \text { عبدالوهاب رمضان عبيه' عبدالفتاح محمود دريسج } \\
& \text { ا ـ معهد بحوث الهنسة الزراعبة - الدقى - الجيزة. } \\
& \text { r. . قسم المنسة الزراعية - كلية الزراعة - جامعة الأزهر - أسيوط الزئ }
\end{aligned}
$$

أجريت هذه الدراسة بقسم الهندسة الزراعية، كلية الزراعة، جامعة عمر المختار، البيضاء، ليبيا.ويهدف هذا البحث إلى نظوير جهاز لقياس مساحة أوراق النباتات باستخدام قياس ضغط الهواء

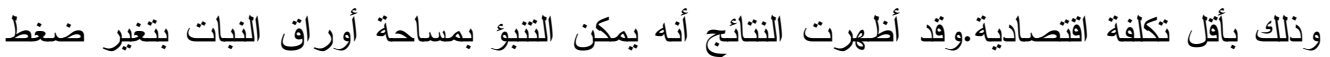
الهو اء، وذلك بإجر اء تحليل الانحدار البسيط. نم حساب أنسب نموذج رياضى يوافق العلاقة بين مساحة الورقة (سمَ) وضغط الهو اء (مللى بار). وقد بينت النتائج وجود علاقة بينمساحة أور اق لقاء النباتات وضغط الهو اء توضحها المعادلة النالية:

$$
Y=9.8624 X^{0.6945 \quad\left(R^{2}=0.9564\right)}
$$

من ناحية أخرى تم تسجيل بيانات مساحة الأوراق للنباتات من الجهاز المطور ومساحة نفس الأوراق من جهاز البلانيميتز وذللك للحصول على معامل التصحيح .أظهرت النتائج أنمعامل التصحيح 0.84، 0.85، 0.86، 0.87، 0.90، 0.92، 1.02، 1.05، 1.08، 1.09لمساحة الورقة النباتية؛ الزيتون، الليمون، مرمرية،بوتس، اللوز،جر انيا، العنب، ورد الزينة، الخوخ و البرقوق، على

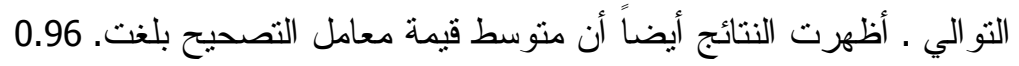

